\title{
Field tests on a grease trap effluent filter
}

\author{
N. H. Wong; *P. L. Law; S. H. Lai \\ Department of Civil Engineering, Faculty of Engineering University of Malaysia Sarawak (UNIMAS), \\ 94300 Kota Samarahan, Sarawak, Malaysia \\ Received 16 January 2007; revised 25 March 2007; accepted 7 May 2007; available online 20 June 2007
}

\begin{abstract}
This study investigates the field performance tests of a commercial grease trap effluent filter for removal of total suspended solids, and oil and grease discharged from the clear zone of full service restaurant grease traps. The grease trap effluent filters were installed on 1,000-gallon, 2,000-gallon and 5,400-gallon full service restaurant grease traps over a period of 8 weeks, and samples were taken at the inlets and outlets. On average, the effluent filters demonstrated to be capable of removing $41 \%$ to $57 \%$ of TSS, and $43 \%$ to $52 \%$ of O and G. Field test data also showed that the total amount of TSS removed by the grease trap effluent filter installed on 1,000 gallon, 2,000 gallon and 5,400 gallon grease traps were approximately $2,542 \mathrm{~kg}, 709 \mathrm{~kg}$, and 2,319 kg, respectively; and the total amount of $O$ and $\mathrm{G}$ removed over the same period were approximately $1,104 \mathrm{~kg}, 271 \mathrm{~kg}$, and $897 \mathrm{~kg}$, respectively.
\end{abstract}

Key words: Total suspended solids, oil and grease, grease trap, effluent filter

\section{INTRODUCTION}

Restaurants discharge wastewaters into public sewers have been a problem for many years, but have become a greater problem with the large number of full service and fast food restaurants being built both in large cities and rural communities (Stoll and Gupta, 1993). These restaurants typically discharge large amount of total suspended solids (TSS) and oil and grease $(O$ and $G$ ) that would reduce the capacity of public sewers over time (Eddy, 1998). The traditional treatment for this waste prior to discharge into the public sewer is a grease trap that causes separation of the floatable and settleable materials (Stoll and Gupta, 1993). Generally, discharge from a grease trap comes from the clear zone created by this separation process. Even though it is called a clear zone, the water from this zone usually contains a considerable amount of relatively low specific gravity suspended solids and high specific gravity $\mathrm{O}$ and $\mathrm{G}$ (Fig 1), (Steward, 1997 and Ecotec, 1996). Recently, the application of a number of commercial grease trap effluent filters had been evaluated as a potential tool for the treatment of TSS and $O$ and $G$ in the clear zone wastewaters (Treanor, 1995). A study performed in Sydney, Australia on a 40 seat cafeteria indicated that the discharge from the restaurant cooking area had

\*Corresponding Author Email: puonglaw@feng.unimas.my Tel.: +6082 672 317; Fax: +6082 672317 an average TSS and $\mathrm{O}$ and $\mathrm{G}$ of approximately 3,024 $\mathrm{mg} / \mathrm{L}$ and 3,630 mg/L, respectively (Ecotec, 1996). It was demonstrated that Ecotec Grease Extractor effluent filter could improve treatment by reducing TSS level to $84 \mathrm{mg} / \mathrm{L}$, and average effluent $\mathrm{O}$ and $\mathrm{G}$ to $78 \mathrm{mg} / \mathrm{L}$ (Ecotec, 1996). The installation of Ecotec Grease Extractor effluent filter on the grease trap resulted in an average $78 \%$ reduction in TSS and $84 \%$ reduction in $\mathrm{O}$ and $\mathrm{G}$ (Ecotec, 1996). Another study performed in Australia concluded that the effect of Taylex Queenland grease trap effluent filter achieved a reduction of the TSS levels by 61\%, and O and G by 63\% (Taylex, 1997). These studies indicated that there is a need for improved treatment and grease trap effluent filters could be an alternative economical option for the treatment of TSS and O and G (Long, 1997). In tank effluent filter installation (Fig. 2) the grease trap effluent filter is designed to reduce the TSS and O and G components of the tank (grease trap) effluent. The exterior of this filter consists of a cylindrical plastic housing 16 inches $(40.64 \mathrm{~cm})$ high and 12 inches (30.48 $\mathrm{cm})$ in diameter with a 4 inch $(10.16 \mathrm{~cm})$ polyvinyl chloride (PVC) couplings, and sheets of plastic in the form of plates comprise of removable interior of the filter. There are 27 individual plates stacked on top of each other with built-in spacers that force the wastewater through the $0.8 \mathrm{~mm}$ openings (Fig. 2). 